\title{
EESTLASENA OLLA JA TÖÖTADA
}

\author{
ENEKEN LAANES
}

„[---] me ei vaja enam eestilisi demonstratsioone, me vajame eestlasena olemist ja töötamist. Ja see ei nõua meilt mingeid sõnalisi armastusavaldusi meie isamaale ja rahvusele." (Tuglas 2004b [1912]: 30)

S irvides noore Tuglase esseistikat, kust selle artikli moto on võetud, kummastab lugejat see, kui vähe on meie kultuuridiskussioon rohkem kui saja aasta jooksul muutunud. Tuglas kaitseb nendes kirjutistes lääne järeleahvimise süüdistuse eest nooreestlasi, neid autoreid ja tekste, mida me praegu mõistame kui kõige väärtuslikumaid eesti kultuuri avaldusi. Ta naeruvääristab etnograafiliselt mõistetud rahvuslikku kultuuri, „koduste kadakate fotografeerimist või ühesoodulist Vanemuise, Kalevipoja ning Manala nime huulil pidamist” (Tuglas 2004a [1911]: 22) ja selle eksporti, „Põhjamaa pärlite” serveerimist Euroopa sigade ette. Päris mürgiste sõnadega salvab ta eesti ajakirjandust, mis pühitseb selle algupäraliseks kuulutatud „Eesti kultuuri võidukäiku iganud, degenereeruva ning variseva Euroopa kultuuri kulul" (Tuglas 2004c [1912]: 36). Kuigi nooreestlaste kriitikute kirjatükke, millele Tuglas vastandub, ei mäleta enam keegi, kas ei tule nende etteheited ja retoorika tuttavad ette?

Juba siis paljurännanud mehena ei vastanda Tuglas rahvuslikkust kosmopoliitsusele, vaid tahab ümber mõtestada rahvuslikku kultuuri ennast. Võõrastest mõjudest ja laenudest rikastatud eesti rahvakunst ei ole tema jaoks sugugi rahvuslikum kui välismaal õppivate ja töötavate nooreestlaste kirjandus ja kunst, mis käsitleb vahel päris võõramaiseid aineid. Sajandi alguses kodumaal nii vihatud moodne eesti kultuur on Tuglase arvates rahvuslik, sest „kunst on ilma teoretiseerimatagi rahvuslik; et keegi ei suuda oma tõu iseloomu ja vaimset valikutunnet salata" (Tuglas 2004a [1911] : 23). Tõu iseloom ja valikutunne on aga „eestlasena olemine ja töötamine” ilma sõnaliste armastusavaldusteta.

\section{1.}

Humanitaar- ja sotsiaalteaduste nüüdisaegne rahvuse käsitlus kujunes XX sajandi viimastel kümnenditel ennekõike filosoofi ja sotsiaalantropoloogi Ernest Gellneri, sotsioloogi Anthony Smithi ja teiste töödes, kes näevad rahvust uusaegse poliitilise, sotsiaalse ja kultuurilise formatsioonina, mis tekkis vastusena industraliseerumisele ja linnastumisele (Gellner 1983; Smith 1991). Need majanduslikud ja sotsiaalsed muutused suurendasid inimeste liikuvust 
ja lõhkusid seniseid tihedaid pere- ning hõimusidemeid, tekitades vajaduse uute ühtekuuluvusvormide järele. Sellist ühtekuuluvustunnet, osalust hakkas pakkuma rahvus, mida määratleti ennekõike suveräänsuse ja kodakondsuse kaudu ning kultiveeriti ühise kõrgkultuuri abil, mille leviku tagasid omakorda kirjaoskus, üldine koolisüsteem, ajakirjandus ja kultuuriinstitutsioonid, nagu muuseumid ja teatrid.

Kuigi rahvused on uusaegne nähtus, käivad nad end peaaegu alati välja igipõlisena. Nad kujutlevad end aegade algusest olemas olnud pika ajalooga kogukondadena. Kõik nimetatud rahvuslusuurijad peavad rahvust moodsaks nähtuseks, kuid nad on omavahel vaielnud selle üle, millist rolli mängisid rahvuste kujunemisel varasemad etnilised ja religioossed kogukonnad. Gellner kaldub arvama, et moodsatel rahvustel ei ole tingimata järjepidevat sidet, nabanööri vanemate epohhide poliitiliste, sotsiaalsete või kultuuriliste kooslustega (Gellner 1997: 90-101). Mõnel võib niisugune side olla, kuid enamasti on see rahvusliku propaganda väljamõeldis. Ta rõhutab, et rahvuslus „ei ole rahvuste eneseteadvusele äratamine: see leiutab rahvused seal, kus neid pole" (Gellner 1964: 169). Ka Eric Hobsbawm ja Terence Ranger räägivad rahvuse „leiutatud traditsioonidest”, mis, kui need puuduvad, tuleb rahvuse legitimeerimiseks välja mõelda (Hobsbawm, Ranger 1983). Smith seevastu rõhutab rahvustele eelnenud etniliste kogukondade tähtsust ja soovitab uurida päritolumüüte, sümboleid, varasemaid uskumusi ja kujutlusi territooriumist ja kogukonna piiridest, millele rahvused toetuvad (Smith 1991: 39). Samas rõhutab ka tema, et rahvuse kujunemine etnilistest kogukondadest ei ole järjepidev. Rahvuslus kasutab varasemaid kujutlusi, sümboleid ja müüte, kuid tõlgendab neid uutmoodi vastavalt oleviku vajadustele (Smith 2001). Ideeajaloolane Eva Piirimäe rõhutab, et rahvuslus on „dünaamiline nähtus”, „valikuline protsess, mille jooksul rahvuse identiteet ja iseloom muutub - ühed identiteedi elemendid asetuvad (ja sageli asetatakse ka teadlikult) esiplaanile, teised tahaplaanile, seejuures muutub teatud osas ka sisu" (Piirimäe 2009: 179). ${ }^{1}$

Kirjandus- ja kultuuriteadustes on kõige mõjukam olnud ehk Benedict Andersoni idee rahvusest kui kujutletud kogukonnast (ingl imagined community). Andersoni jaoks on rahvus kujutletud selles mõttes, et selle liikmed ei tunne üksteist, aga kujutlevad end siiski kokkukuuluvatena. Sarnaselt Gellneri ja Smithiga on rahvus Andersoni jaoks uusaegsete majanduslike ja sotsiaalsete arengute vili, kuid tema peab seda ennekõike kultuuriliseks süsteemiks, mis ei sarnane mitte niivõrd poliitiliste ideoloogiatega, kuivõrd rahvuslusele eelnenud suurte kultuurisüsteemidega nagu näiteks religioossed kogukonnad. Andersoni arvates ei tohiks rahvuslust kritiseerida kui vulgaarset kirge, vaid seda tuleks võtta tõsiselt kui sotsiaalse ja poliitilise elukorralduse vormi, millel on sügavad kultuurilised juured. (Anderson 2003 [1983])

Konstruktivistlikke rahvuslusteooriaid mõistetaksegi sageli valesti selles mõttes: kui öelda, et miski on kujutluslik, siis tähendab see paljude jaoks seda, et see on tehislik või et seda pole päriselt olemas ja seetõttu pole see oluline. See arusaam on ekslik. Rahvused toetuvad enese kujutlemisel varasematele

${ }^{1}$ Vt Piirimäe artiklit kui üht parimat eestikeelset ülevaadet erinevatest rahvusluse teooriatest. 
kultuuritraditsioonidele ja on seetõttu võimsad ja mobiliseerivad kultuurilised ja sotsiaalsed struktuurid.

Lisaks kultuurilistele juurtele huvitavad Andersoni moodsad kultuuritehnoloogiad, nagu ajakirjandus ja romaanikirjandus, mis tegid rahvuste kujutlemise võimalikuks. Andersoni arvates aitas just XIX sajandi romaan kujutleda rahvust, sest tänu paljudele tegevusliinidele näitab see, mida teevad samal ajal erinevad tegelased, kes ei pruugi üksteist tunda. Kasutades Walter Benjamini sõnastust moodsa ajateadvuse kohta, ütleb Anderson, et romaan aitas oma vormilise eripäraga luua ideed „sotsioloogilisest organismist, mis liigub kalendri järgi läbi homogeense tühja aja. See ettekujutus oli rahvuse idee täpne analoog" (Anderson 2003 [1983]: 26). Romaan lõi niisiis ajateadvuse abil kujutluse kogukondlikust ruumist, kus inimesed ei pruugi üksteist teada, aga tunnevad sellest hoolimata ühtekuuluvustunnet, kuna liiguvad kõik koos läbi aja. Selline kogemuse korrastamise viis võimaldas mõelda suurest hulgast üksikisikutest kui kokkukuuluvast kogukonnast.

Teiseks rahvuse kujutlemise kultuuritehnoloogiaks peab Anderson ajakirjandust. Igapäevane ajakirjanduse tarbimise rituaal, mille käigus suured inimhulgad loevad sama päeva jooksul samadest sündmustest kodus ja välismaal, tekitab rahvusliku kogukonna, millel on ühine avalik ruum. Eesti kontekstis, kus maadeldakse elanikkonna asumisega erinevates meediaruumides, peaks ajakirjanduse kogukonda loov jõud olema ilmne ka nüüdisajal.

Väites, et rahvus on kujutletud kogukond, ei ole rahvuslusteooriad veel midagi öelnud selle kujutlemise viiside kohta, selle kohta, milline on selle ideoloogiline sisu. Anderson ütleb, et kogukondi saab eristada „mitte nende tehislikkuse või loomulikkuse, vaid nende kujutlemise stiili järgi” (Anderson 2003 [1983]: 6). Rahvusluse uurijad jagavad rahvuse kujutlemise viisid laias laastus kaheks: kultuurrahvusluseks, mis „rõhutab ühist päritolu ning kultuuri (keelt, religiooni)”, ja kodanikurahvusluseks, mis peab tähtsaks „ühist territooriumi ning poliitilisi institutsioone (riiki)" (Piirimäe 2009: 172). Toetudes moodsatele rahvuslusteooriatele, ongi kriitiline humanitaaria viimaste aastakümnete jooksul näinud oma rolli rahvuse kujutlemise viiside, rahvusluse ideoloogilise sisu uurimises ja vajadusel ka poliitilises kriitikas. Rahvuse kujutlemise viisid on ajas muutuvad. Nad on alati mingi vastus aja ja olude nõudmistele. Kui need muutuvad, muutuvad ka rahvuse kujutlemise viisid, vahel küll suurte vaidluste ja kultuurisõdade käigus.

Eestis levinud rahvusteaduste mõiste, mis määratleb humanitaarteadusi rahvust teenindavate teadustena, on selles mõttes vastuolus nende viimaste kümnendite rahvusvaheliste arengutega. Keeleteadlane Urmas Sutrop on kritiseerinud 2005. aastal vastu võetud haridus- ja teadusministeeriumi määruses „Teadus- ja arendusasutuste baasfinantseerimise määramise tingimused ja kord" kehtestatud rahvusteaduste definitsiooni. Selle järgi on rahvusteadused Eesti ajalugu, folkloristika, keeleteadus, kunstiteadus (sh muusika- ja teatriteadus) ja kirjandusteadus, aga ka teised teadused, „mille uurimistulemustel on otsene mõju eestlaste enesemääratlusele ning mis sellega aitavad kujundada ja säilitada eestlaste identiteeti" (Teadus- ja arendusasutuste... 2005). Sutrop peab humanitaarteaduste rakendamist identiteediloome teenistusse kitsaks ja utilitaristlikuks ja pakub välja, et „rahvusteadus on igasugune teadus, mis on seotud kultuuriga ja kohavaimuga, genius loci'ga” (Sutrop 2012: 
1172). Rahvusteaduste mõiste käibesse tulek teaduspoliitilises kontekstis, kus humanitaarteaduste seostamine rahvuse ja identiteediloomega on ainus viis, kuidas tagada nende jätkusuutlik rahastus olukorras, kus teaduse peamine mõõdupuu on reaalteaduslik rakenduslikkus ja utilitaristlikult mõistetud „kasulikkus” ühiskonnale, on mõistetav. Kuid see teaduspoliitiline kasutus ei tohiks ähmastada meie arusaama humanitaaria ja rahvuse suhetest ning juurutada ideed, nagu oleks humanitaarteaduste eesmärk luua rahvuslikku identiteeti. Pigem uurib kriitiline humanitaaria, kuidas need kujutlemise viisid tekivad ja muutuvad.

\section{2.}

Samal ajal kui lugesime läinud sügisel üliõpilastega Andersoni raamatut rahvusest kui kujutletud kogukonnast, ilmus Eesti ajakirjanduses rida teemakohaseid arvamusartikleid, mis andsid hea ülevaate ühiskonnas praegu toimuvast võitlusest erinevate rahvuse kujutlemise viiside vahel. Selle arutelu üheks läbivaks jooneks on konservatiivsete kolumnistide võitlus sotsiaalkonstruktivismi ja „multikulti” tontidega, mis olla pea peale pööranud „sajandeid kasutusel olnud ja väärtustele viitavad sõnad” (Nutt 2017). Mart Nutt vastustab artiklis „Rahvas pole kogukond” sõna kogukond kasutamist rahvusgruppide kohta ja väidab, et selle sõna abil tahetakse välja tõrjuda mõisteid rahvas ja rahvus (mida Nutt kasutab sünonüümidena), aga ka põliselanikud ja immigrandid, rahvusriik ja kodumaa. Need tahetavat tema arvates asendada sõnadega mitmekultuurilisus ja põhiseaduslik patriotism. Kuigi Nutt vastustab sõnakasutust, ei ole tema tegelik mure siiski mitte sõnad, vaid asjad, mida nendega nimetatakse. Ta tahab, et rahvast/rahvust nimetatakse endiselt rahvuseks, mitte kogukonnaks, sest ainult siis saab rääkida põlisrahvusest, diasporaast ja immigrantidest ning on tagatud „elanike jagamine põlisuse, rahvuskuuluvuse” alusel. Sellist ihaldatud jaotust toestab ta traditsiooniliselt osundusega Eesti põhiseadusele, mis ütleb, et Eesti riik põhineb „Eesti rahva riikliku enesemääramise kustumatul õigusel” ja peab „tagama eesti rahvuse, keele ja kultuuri säilimise läbi aegade" (Eesti Vabariigi põhiseadus). Mida Nutt näib oma terminoloogiavaidluseks maskeeritud arvamusartikliga taotlevat, on põlisrahvuse mõiste abil privileegide nõutamine ühele osale elanikkonnast, samal ajal kui mitmekultuurilisuse ja põhiseadusliku patriotismi sõnavara ähvardab anda ka teistele Eestis elavatele inimestele võimaluse kuuluda rahvuse hulka.

Nutt esitab kogukonda feodalistliku ühiskonna nähtusena, rahvust aga moodsa demokraatia omana, just nagu Gellner ja Smith, ja siin jooksebki tema argumentatsioon ummikusse. Demokraatlik ühiskond, mida Nutt määratleb üldisel valimisõigusel põhinevana, toetub kodanikele, kelle selline staatus ei ole seotud nende etnilise rahvusega. Kui sa oled kodanik, siis pole oluline, kas sa oled põlisrahva liige või mitte. Rääkides läbisegi rahvast ja rahvusest, näitab Nutt, et tegelikult kasutab ka tema ise rahvuse mõistet kodanikurahvusluse ehk põhiseadusliku patriotismi mõttes. Kui Eesti Vabariigi põhiseadus räägib Eesti rahva riiklikust enesemääramisest, siis räägib see rahvast kui kodanikkonnast ega ütle midagi nende kodanike etnilise rahvuse kohta. Konservatii- 
vid võitlevad mõistagi põlisrahvuse mõiste eest, sest see pakub paljudele teenimatut privileegi tunda end sel maal tähtsamana kui mõne teistsuguse etnilise taustaga inimesed, kuid Eesti põhiseadusega seda põhjendada ei anna.

Kui meie kõigi eluiga on laias laastus sama pikk, siis kuidas on mõned meist sellel maal põlisemad kui teised muudmoodi kui vaid kujutluslikult? Lisaks, kui üks mu vanematest on eestlane ja teine mõnest teisest rahvusest, olen ma siis veel põlisrahva liige, on mul siis veel põlisrahva õigused? Ja kui need õigused ei ole individuaalsed, vaid kollektiivsed, siis mis ma peaksin sellise „segaverelisena” tegema, et nad ka minule laieneksid? Kas rääkima aktsendita eesti keelt, käituma nagu eestlane, kujutlema end eestlasena? Aga kas sellisel viisil pole mitte igaühel võimalik saada eestlaseks, ükskõik milline on tema etniline taust? Lõpuks saame rääkida vaid eesti rahvusest kui kodanikkonnast ja eesti keelest kui selle riigi riigikeelest, aga mitte enam etnilisest rahvusest. Nuti rahva ja rahvuse samastamine viib tema enda argumendi absurdi.

Sotsiaalkonstruktivismi ja „multikulti” tontidega võitleb oma arvamusavalduses ka Mihkel Mutt. Artiklis „Hämaruse kaks kämmalt” peab ta end valgustatud rahvuslaseks, kellele pole meelt mööda ei marurahvuslased ega kosmopoliidid. Tema jaoks tähendab rahvuslus omasuguse eelistamist, mis on „looduse poolt vaikimisi antud seade” (Mutt 2017). Mille alusel ta aga omasuguseid kindlaks teeb, jääb arusaamatuks. Ta räägib välismaalastest, keda tänaval kohtab ja keda eristab nahavärvi ja silmalõike järgi, justkui oleks tänapäeva eestlased kõik üht nahavärvi ja ühe silmalõikega. Ekslikult taandab ta (maru)rahvusluse kriitika nende kadeduseks, kes ise rahvustunnet ei tunne, „valgustuslikuks dotseerimiseks ideesõdalaste poolt, kellel puuduvad sügavamad tunded” (Mutt 2017). Nii ähmastab Mutt ühiskonnas toimuvat debatti, kus küsimuse all ei ole rahvusluse kui sellise kriitika, vaid vaidlus rahvusluse ideoloogilise sisu üle, selle üle, kuidas eesti rahvust kujutleda.

Kaude võttis oma Riigikogu sügisese istungjärgu avamisel peetud kõnes rahvusküsimuses seisukoha ka Eesti Vabariigi president Kersti Kaljulaid. Ta ütles: „[M]itte keegi ei saa monopoliseerida eestlaseks olemise uhkust. Mitte keegi ei saa meilt nõuda vabadustest loobumist, et saaks sinimustvalgem. Mitte keegi ei saa piirata meie vaba enesemääramist, et saaks sinimustvalgem. [---] Mitte keegi ei tohi pidada vähem sinimustvalge lipu alla kuuluvaks neid kaaskodanikke, kes pärinevad teisest keelest või kultuurist. [---] Sinimustvalget genofondi ei ole olemas. On eesti keel, kultuur, kombed, tavad ja harjumused." (Kaljulaid 2017) Eesti ajakirjandus on suuresti maha maganud selle suure ideoloogilise pöörde, mille Eesti presidendi institutsioon on Kersti Kaljulaiu ajal läbi teinud, ja pole suutnud mõtestada neid olulisi uusi teemasid, mille Kaljulaid on jõuliselt meie avalikku debatti toonud, olgu selleks sooline võrdsus, sotsiaalne õiglus või rahvusküsimus. Osundatud kõnes ütleb ta selgesti, et eesti rahvuslus saab olla vaid kodaniku-, mitte etniline rahvuslus, ja selle väärtusteks on keele, kultuuri ja kommete kõrval ka inimõigused ja vabadused.

Presidendi sõnavõtust ajendatuna puhkes väike debatt ka eesti populatsioonigeneetikute hulgas, kes asusid vaidlema selle üle, kas Kaljulaid kasutas oma seisukoha väljendamiseks õigesti nende erialast sõna genofond. Mart Viikmaa ei pea presidendi väidet sinimustvalge genofondi puudumisest 
õigeks. Ta väidab, et rahvuslik genofond on olemas: „Igas populatsioonis, kus isendid paarituvad omavahel oluliselt sagedamini kui naaberpopulatsioonide isenditega, erineb selle genofond mingil määral kõigi teiste omadest" (Viikmaa 2017). Näiteks olevat eestlased teiste rahvaste genofondiga võrreldes pikakasvulisemad ja vähem pigmenteerunud. Viikmaa mure sinimustvalge genofondi mittetunnistamise pärast on sarnane Nuti omaga. Ta ei saa nõustuda Kaljulaiu väitega, et igaüks, kes oskab eesti keelt, tunnustab eesti kultuuri ja peab end eestlaseks, ongi eestlane, sest see seadvat vähe piiranguid vabale enesemääramisele eestlasena, piisavat vaid keele õppimisest. Samas jätab Viikmaa tähelepanuta asjaolu, et relatiivselt määratletud genofondi tunnuste alusel saab populatsioone omavahel eristada, aga ei saa üksikuid indiviide sinna sisse või välja arvata. Eks ole ju ka lühikesi ja rohkem pigmenteerunud eestlasi, suhteliselt pikad ja vähepigmenteerunud on nad vaid kõik koos võrreldes mingi teise kooslusega.

Evolutsioonigeneetik Mait Metspalu (2017) selgitaski seepeale, et populatsioone saab genofondide alusel eristada tõesti üksnes siis, kui nad saavad või on saanud järglasi vaid oma populatsioonikaaslastega. Ta näitab, et end eestlasteks pidava rahva geneetiline ajalugu on kirju (genofond on moodustunud mitme sisserände laine tagajärel) ja näiteks võrokesed on geneetiliselt sarnasemad lätlastega kui läänevirulastega. Metspalu ütleb isegi, et nad on lätlastest ja läänevenelastest eristamatud. Seega saab sinimustvalgest genofondist rääkida vaid siis, kui enne uurima asumist on erinevate rahvuste genofondid juba ette piiritletud valitsevate rahvusmääratluste abil (et piir läheb eestlaste ja lätlaste, mitte põhja- ja lõunaeestlaste vahel). Alles seejärel saab leida neid genofonde eristavad tunnused. Geneetikute väike debatt näitas hästi, kuidas ideoloogilised rahvuse kujutlemise viisid mõjutavad mitte ainult humanitaar-, vaid ka reaalteadusi, laiem arutelu aga seda, et Eestis on käimas tuline vaidlus rahvusluse ideoloogilise sisu üle ja rahvus kui kategooria, mille suhet humanitaarteadustega käesolev teemanumber üritab mõtestada, on Eestis suures muutumises.

\section{3.}

Etnilised eestlased, mida iganes see erinevatel epohhidel on tähendanud, ei ole sellel maal pea kunagi elanud omaette. Vallutuste ja anneksioonide tulemusena on nad seda maad alati pidanud jagama teistsuguse etnilise taustaga inimestega. Me ei ole kunagi saanud valida, ei saa praegu ega ka tulevikus valida, kellega koos me siin elame, nii nagu me ei saa valida, kes on meie naabrid või kellega me jagame seda planeeti. 2017. aasta inimarengu aruandes „Eesti rändeajastul” tegid rahvastikuteadlased puust ja punaseks, et isegi kui meil õnnestuks tõsta sündimus soovitud tasemele, mis on ebatõenäoline, ei ole Eesti riigil ilma sisserändajateta võimalik majanduslikult toimida, hoida isegi praegust elustandardit, rääkimata selle parandamisest (Eesti inimarengu aruanne 2016/2017). Inimarengu aruande esitlusel Riigikogus oli huvitav jälgida, kuidas parlamendiliikmed ei suutnud rahvastikuteadlaste arvude keeles edastatud sõnumit vastu võtta ja hakkasid arutama selle küsimuse kui poliitilise valiku, mitte kui majandusliku möödapääsmatuse üle. Eesti saab olema 
riik, kus teistest maadest pärit inimeste arv on määratud kasvama. Viljakam kui selle eitamine on mõtlemine selle üle, kuidas elu selles olukorras paremini korraldada. Ainus, mis eestlastel on võimalik teha, nii nagu meil on seda võimalust harva olnud, on valida neid viise, kuidas edendada elu sellel maal paremini, kui on teinud varasemad valitsejad, paremini kõigi nende inimeste jaoks, kes siin elavad ja kes on määratud siia elama. Ja see viib meid tagasi küsimuse juurde rahvuse kujutlemisest. Praeguses ühiskondlikus debatis ei ole küsimus rahvusluses või selle vaenamises, vaid selles, millised on need parimad viisid, kuidas olla patrioot ja edendada Eestit. Paradoksaalselt on Eesti rahvuse, keele ja kultuuri ellujäämise võti, nagu ta seda on alati olnud ja nagu ta seda oli ka noore Tuglase ajal, seisneb just valmiduses ja võimes muutuda. $^{2}$

Kitsas etniline ja keeleline arusaam eestlaseks olemisest võib olla suures osas Nõukogude okupatsiooni pärand. Kaks totalitaarset režiimi aitasid meil, ja mitte meie endi osaluseta, saada lahti ajaloolistest etnilistest vähemustest, baltisakslastest ja juutidest. Kuid õige pea toodi siia uued inimesed, kes rääkisid teist keelt. Oma riigi kaotus, järgnenud venestamine, keele ja kultuuri allasurumine aitasid kujundada vastupanulist ettekujutust eesti rahvusest, mis koosneb vaid etnilistest eestlastest, kes räägivad emakeelena eesti keelt ja kannavad edasi algupärast eesti kultuuri. Kuigi ka siis oli inimesi, kes rõhutasid nõukogudeaegse eraldatuse vastukaaluks rahvuskultuuri avatust. 1976. aastal kirjutab Lennart Meri oma „Hõbevalges”: „Usun, et kultuurikontaktid ei ole uus nähtus, vaid uus kvaliteet. Nad on alati toiminud, nii kaugele kui silm ulatab seletama. Jaotugu nad ajas hõredalt nagu kosmiline tolm, ajavool annab neile massilisuse ja kaalu. Ühtse kultuuriloo taustal peaksime niinimetatud rahvuslikes tunnustes nägema ajalisi ja ajutisi nähtusi, mida ei saa absolutiseerida ega konservipurki sulgeda, veel vähem kõrvalmõjudest puhtaks filtreerida, et niiviisi jõuda mingi eheda algkultuurini. See nostalgilise hõnguga igatsus osutub steriilseks mõttekujutluse viljaks, mida tegelikkuses pole olnudki. Arengu ja avastuste paatos peitub kultuurikontaktide jälgimises ja teadlikus arendamises." (Meri 1976: 482) Nagu Tuglas, näeb ka Meri rahvuslikku kultuuri kultuurimõjude põiminguna, millele annab oma ainulisuse kultuuri kohalikkus.

Nõukogude ajal ununes asjaolu, et Eesti Vabariik oli mitmekultuuriline maa ja selle patriotism toetus suures osas demokraatlikele väärtustele. Selle mitmekultuurilisuse mõistmiseks ei pea tingimata lugema Carl Mothanderi või Dagmar Normeti mälestusi, piisab Jaan Krossi, paljude jaoks selle kõige õigema ja väärikama Eesti-ehitaja loomingust, kes oma 1980. ja 1990. aastate romaanides otsustas kujutada/kujutleda vabariigiaegset Eestit eranditult mitmekultuurilise maana, kus ülimaks väärtuseks ei olnud mitte etniline rahvus, vaid „olemine ja töötamine” selle maa ja riigi hüvanguks.

Meie avalikkust valdav kujutlus eestlaseks olemisest toetub endiselt nõukogudeaegsele põlvkonnale, kuid on mitmes mõttes ajast ja arust. Eestlased on põlisrahvas, need, kelle vanemad on eestlased ja kes räägivad eesti keelt;

${ }^{2}$ Näitena sellest, kuidas kultuur, sealhulgas keel kogu aeg muutub, vt artikli motoks oleva Tuglase osunduse algupärast versiooni: „Meil ei ole tarvis enam eestilikka demonstratsionisid, meil on tarvis eestlasena elamist ja töötamist. Ja see ei nõua meilt mingisuguseid armastuseavaldusi meie isamaa ja rahvuse vastu". (Tuglas 1912: 263) 
venelased on sisserändajad, need, kelle vanemad on venelased ja kes ei räägi eesti keelt - see kujutlus Eesti inimestest suri reaalsuses juba paar aastakümmet tagasi. Meie koolid on täis segaperekondadest lapsi, mitte ainult eesti-vene, vaid igasugustest erinevatest segaperekondadest lapsi, kes on kaks- või kolmkeelsed. Meil on vene perekondadest pärit lapsi, kelle esimene keel, see, mida nad oskavad kirjakeelena kõige paremini, on eesti keel. Meie koolides on etnilisi eestlasi, kes tulles Soomest või Saarest (või Brüsselist), peavad eesti keele kirjakeelena alles korralikult ära õppima. Meie koolides on tumedanahalisi eestlasi, kes tulevad vahetusõpilastena oma ema- või isamaale Iirimaalt ja mujalt. Need ei ole ainult privilegeeritud majanduskosmopoliitide lapsed, need on ka 1990. aastate alguse vabadusetuhinas maailma avastama läinud noorte ja majanduskriisidest räsitud maalt väljarännanute ja nüüd tagasi tulnute lapsed. Ja neid kõiki on palju. Nad on siin ja nad tahavad siia kuuluda, kui neile selleks võimalus antakse. See, kas neist saavad eestlased, oleneb rohkem meist kui neist, suuresti sellest, kui avaralt me kujutleme eesti rahvust.

Kui Jürgen Ligi nimetas 2014. aastal Jevgeni Ossinovskit „sisserändaja pojaks roosast erakonnast” ja hiljem tema ees vabandas, siis tegi ta Ossinovskile komplimendi tema eesti keele kohta, öeldes: „[---] imetlen tema Eesti-meelsust ja keeleoskust" (Kaukvere 2014). See repliik kujustab suurepäraselt meie avalikku arvamust kujundava vanema põlvkonna arusaama sellest, kes on eestlane ja mida tähendab eesti keele rääkimine. Ligi näitas oma komplimendiga üles üüratut umbusku Eesti kooli ja tema võimekuse suhtes integreerida teistsuguse taustaga inimesi eesti keelde ja kultuuri. Talle ei tulnud pähe, et 1986. aastal sündinud mees, kes on õppinud Eesti koolis, võiks rääkida eesti keelt sama hästi kui ta ise, et tal võiks olla selle keelega samasugune suhe nagu temal. Kohane vastus Ligi repliigile oleks olnud teha vastukompliment, kiita ka tema enda eesti keelt, mida ta oma sagedaste teravuste sõnastamisel ajuti päris meisterlikult kasutab.

Marurahvuslastest poliitikud on viimastel aastatel näinud kõvasti vaeva, et lörtsida eestlust ja tempida seda kolkluse ja võõravihaga. Kuid see ei ole neil õnnestunud. Eestlus on palju avatum ja enesekindlam, palju maailmaahnem ja võimelisem maailma endasse haarama. Paljud inimesed, kes vastustavad neid eestlaste nimel rääkimise katseid, ei ole lasknud endalt võtta eestlaseks olemise privileegi, siin maal elavate inimeste võõrandamata õigust eestlust kujutleda. Mait Metsanurga ja Jaan Koorti kodukandis kasvanud maatüdrukuna, seppade, renditalunike ja kooliõpetajate järeltulijana, kelle esivanemad on elanud paikselt ühes kandis sajandeid, pean ennast nii sügavalt juurdunud inimeseks, et ükski katse kaaperdada eestlust poliitilistel eesmärkidel ei ole tekitanud minus soovi sellest lahti öelda, pigem vastupidi.

Kuigi Valdur Mikita rahvuse kujutlemise viisid pole päris minu maitse, on tema ja paljude teiste eesti kirjanike viis seostada rahvuslikku identiteeti maa ja maastikega minulegi lähedane. 1990. aastate alguses tundsin end tihti nagu XX sajandi alguse eesti haritlane, kes pani heina rõuku, tõi jõhvikad soost koju, võttis kartulid üles, ja läks siis sügisel Euroopasse ülikooli. Sellest, et eestlus tähendab minu jaoks seotust maa ja maastikega, sain aru siis, kui esimesel Eestist eemal oldud suvel lounamaa suurlinnas lämmatavas leitsa- 
kus hakkasin öösiti unes nägema Eesti maastikke, jahutava tuulega rohelisi heinamaid.

Eesti üks suuremaid luuletajaid, minu jaoks nii eesti maastikke kui ka eestlasena olemist ja töötamist kõige paremini mõtestanud eesti poeet Jaan Kaplinski on kirjutanud nii:

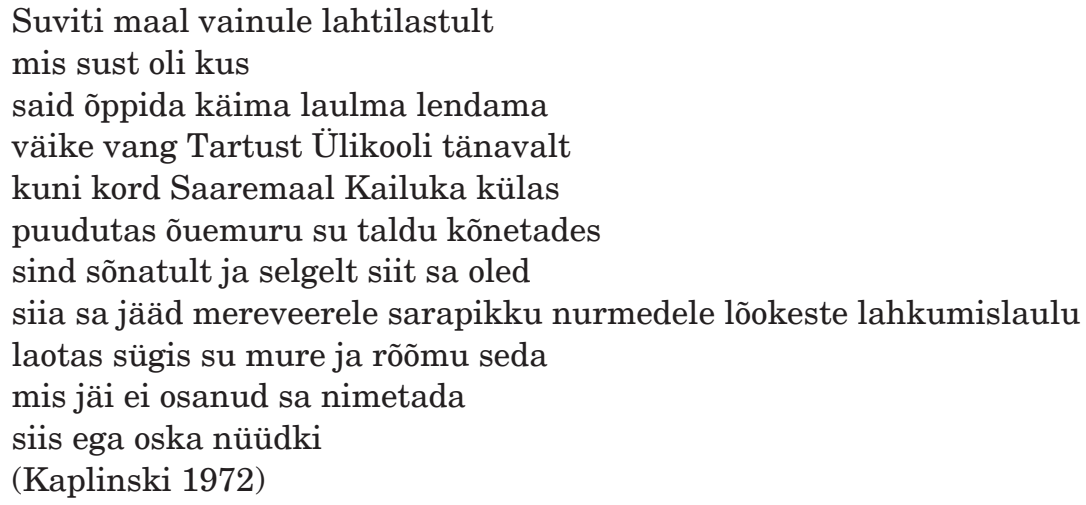

Võib-olla ei ela neid hetki, mil Kailuka või mõne muu küla õuemuru või linnatänava asfalt kõnetab me jalataldu, hetki, mil otsustame kuhugi kuuluda, mitte ainult suured „segaverelised” eesti poeedid, vaid meie kõik, ükskõik kui põliseks me end sel maal peame, ükskõik, kas me oleme siin sündinud või mitte. Eestlasena olla ja töötada, sellest piisab, ükskõik kas siin või väljamaal. Midagi rohkemat pole eestlaseks olemiseks vaja.

Tulles lõpetuseks tagasi humanitaarteaduste ja rahvuse juurde, tuleb rõhutada, et lisaks rahvuse kujutlemise viiside eritlemisele uurib kriitiline humanitaaria ka omaenda ajaloolist rolli rahvuste kujutlemisel. Sellisena ei ole humanitaarteadused apoliitilised, vaid on mässitud rahvuse kujutlemise protsessi. Nagu näitas 2013. aastal „Eesti ajaloo” II köite ilmumise järel lahvatanud ajalootüli, on rahvuse kujutlemise viiside kriitika teatud määral rahvust kujutlev poliitika. Kui me kritiseerime neid viise, kuidas näiteks ajalooteadus on aidanud eesti rahvust määratleda, siis pakume paratamatult välja alternatiivseid viise selle kujutlemiseks.

\section{Kirjandus}

Eesti Inimarengu Aruanne 2016/2017. Eesti rändeajastul. Eesti Koostöö Kogu. https://inimareng.ee (14. I 2018).

Eesti Vabariigi põhiseadus. - Riigi Teataja, RT 1992, 26, 349. https://www.riigiteataja.ee/akt/633949 (14. I 2018).

And ers on, Benedict 2003 [1983]. Imagined Communities Reflections on the Origins and Spread of Nationalism. London-New York: Verso.

Gellner, Ernest 1964. Thought and Change. London: Weidenfeld and Nicholson.

Gelln e r, Ernest 1983. Nations and Nationalism. Ithaca-New York: Cornell University Press.

Gelln er, Ernest 1997. Nationalism. London: Weidenfeldt \& Nicholson. 
Hobsbawm, Eric, Ranger, Terence (toim) 1983. The Invention of Tradition. Cambridge: Cambridge University Press.

Kaljulaid, Kersti 2017. Vabariigi president Riigikogu avaistungil. https://www. president.ee/et/ametitegevus/koned/13543-vabariigi-president-riigikogu-avaistungil/index.html (14. I 2018).

Kaplinski, Jaan 1972. Kuusikut sa mäletad tiiki ja mesipuid. - J. Kaplinski, Valge joon Võrumaa kohale. Tallinn: Eesti Raamat, lk 25.

Ka ukvere, Tiina 2014. Jürgen Ligi palus vabandust. - Postimees 23. X. https:// www.postimees.ee/2964541/jurgen-ligi-palus-vabandust (14. I 2018).

Meri, Lennart 1976. Hõbevalge. Tallinn: Eesti Raamat.

Mets palu, Mait 2017. Kaljulaid ei eksinud. - Postimees 20 XII. https://arvamus. postimees.ee/4315499/mait-metspalu-kaljulaid-ei-eksinud (14. I 2018).

Mutt, Mihkel 2017. Hämaruse kaks kämmalt. - Postimees 14. IX. https://arvamus.postimees.ee/4243953/mihkel-mutt-hamaruse-kaks-kammalt (14. I 2018).

Nutt, Mart 2017. Rahvas pole kogukond. - Postimees 20. VIII. https://arvamus. postimees.ee/4216401/mart-nutt-rahvas-pole-kogukond (14. I 2018).

Pi ir imä e, Eva 2009. Teoreetilisi perspektiive 19. sajandi eesti rahvusluse uurimiseks. - Vene Impeerium ja Baltikum: venestus, rahvuslus ja moderniseerimine 19. sajandi teisel poolel ja 20. sajandi alguses. (Eesti Ajalooarhiivi toimetised 16 (23).) Toim Tõnu Tannberg, Bradley Woodworth. Tartu: Eesti Ajalooarhiiv, lk 167-191.

S mith, Anthony D. 1991. National Identity. London: Penguin.

Smith, Anthony D. 2001. Nationalism: Theory, Ideology, History. Cambridge: Polity.

Sutrop, Urmas 2012. Kuidas me mõistame rahvusteadust? - Akadeemia, nr 7, lk 1155-1177.

Teadus- ja arendusasutuste baasfinantseerimise määramise tingimused ja kord. Riigi Teataja, RTL 2005, 34, 483. https://www.riigiteataja.ee/akt/130082017016 (14. I 2018).

Tuglas, Friedebert 1912. Eesti Euroopas. - Noor-Eesti IV. Helsingi: E.K.S. NoorEesti väljaanne, lk 257-268.

Tuglas, Friedebert 2004a [1911]. Üks Põhjamaa pärl. - F. Tuglas, Kogutud teosed X. Kriitika VII. Tallinn: Underi ja Tuglase Kirjanduskeskus, lk 20-24.

Tu gl a s, Friedebert 2004b [1912]. Natukene Kapitooliumist ja hanedest. - F. Tuglas, Kogutud teosed X. Kriitika VII. Tallinn: Underi ja Tuglase Kirjanduskeskus, lk 25-35.

Tuglas, Friedebert 2004c [1912]. Eesti Euroopas. - F. Tuglas, Kogutud teosed X. Kriitika VII. Tallinn: Underi ja Tuglase Kirjanduskeskus, lk 36-44.

Viikmaa, Mart 2017. President Kaljulaid poliitilise korrektsuse teenistuses. Postimees 13. XI. https://arvamus.postimees.ee/4308677/populatsioonigeneetikmart-viikmaa-president-kaljulaid-poliitilise-korrektsuse-teenistuses (14. I 2018). 


\section{To be and to work as an Estonian}

Keywords: imagined communities, civic nationalism, Fridebert Tuglas

The article deals with the relevance of the idea of the nation in the contemporary Estonian public debate about language, culture and and belonging. It first offers a brief overview of the most important contemporary theories of nationalism and argues that in the recent decade the critical humanities internationally have seen their role in the critical reflection and in the political critique of different ways of imagining the nation. The article then moves on to examine the current Estonian public debate which is often mistakenly framed as an opposition between nationalism and cosmopolitanism. Instead, what seems to be at stake in this debate is the question about patriotism and of the ways how to be Estonian in contemporary times of globalisation and intense migration. In going back to the example of the period of intense renewal and rethinking of Estonian culture and nation at the beginning of the 20th century, the articles argues for the need to enlarge the current ethnically and culturally defined understanding of Estonian nation and to replace it with civic nationalism that enables the inclusion of people with different ethnic and cultural background living in Estonia.

Eneken Laanes (b. 1972), PhD in World Literature, Under and Tuglas Literary Centre, Senior Researcher; Tallinn University, Associate Professor of Comparative Literary Studies,eneken@utkk.ee 